\title{
QUALITATIVE INTERPRETATION AND SAMPLING VALIDITY OF PEER RECOGNITION STUDY
}

\author{
R. CRICKMAN* \\ University of Minnesota, Minneapolis, Minnesota 55455, USA \\ C. BARR $\dagger$ \\ AND \\ M. KOCHEN" \\ University of Michigan, Ann Arbor, Michigan 48109, USA
}

\begin{abstract}
In an examination of limitations to a previous study, it was found that there was no significant difference between respondents and non-respondents with regard to country or eminence of institution. Observations from non-respondents illustrate possible constraints on the interpretation of responses.
\end{abstract}

\section{INTRODUCTION}

This note supplements an earlier paper (Blaivas et al., 1981), in which we reported the results of a study aimed at describing how peers are recognized among experts in a specialty.

While the limitations to our study resulting from the potential for bias due to geographical and eminence-of-institution differences between respondents and non-respondents are negligible, the observations (see Appendix) from nonrespondents who chose to comment in depth on our request suggest the limitations that probably do constrain our interpretation of the responses. The feelings of these non-respondents from whom we heard certainly echoed those of many of the respondents, who frequently offered comments as well as nominations, and probably reflected similar judgments on the part of non-respondents who never replied in any way.

We, and, presumably, our readers, are particularly interested in the contributions of peer review and interactions to the dynamics of scientific research. Depending on the field and the individual, the act of generating a

*Biographical notes on Robin Crickman and Manfred Kochen appeared in Social Science Information Studies, $1,238$.

†Charles Barr is Research Assistant in Information Science at the Mental Health Research Institute and a graduate student at the School of Natural Resources, University of Michigan. 
limited list of names is an artifact, distorting to a greater or lesser degree the truth about peer interactions. Many of our respondents accepted the spirit of our inquiry and the limits and ambiguities of our solicitation, and they are to be thanked for contributing to our database. The increasing inaccuracy with passing time of a given list of nominations in relation to a respondent's creative peer network was not of obvious concern to anyone: trying to profile the changing lists that each individual would generate, say, every other year, would be a truly ambitious exercise in experimental design. But the feeling seemed very prevalent that it was in some ways equally ambitious, and susceptible to distortions, to get a list generated at one time, and that in some cases a partial network (a smaller number than they would like, or a list applying to only one of several areas of interest) was a less preferable alternative than no list at all.

Our technique also fails to distinguish between degrees and qualities of peer communication. The exhortation to name peers 'whose work you try to keep up with, and whose competence, creativity and judgment you respect' can result in a set of names but still fails to control ambiguities of individual interpretation. Analysis of the database can determine the extent to which the nominated reciprocate the nominators by naming them in turn, and this strengthens our grasp of the kinds of networks each is a part of.

But we accept, in part, that the loner, maverick or interdisciplinarian (an identity that all scientists partake of to a degree) and his or her interactions would be most accurately profiled by a more detailed inquiry than our method permits. The student of science needs to refer to personalized 'longitudinal' studies, e.g., The eighth day of creation (Judson, 1979) and An imagined world (Goodfield, 1981), to complement our method. The role of mavericks in the dynamics of scientific research may be crucial: responsibility for discovery, paradigm-breaking and so on might be attributed largely to this group. Yet they and their less maverick peers participate in networks whatever their sense of isolation, individuation and ambiguity. Our method, while it cannot capture the human element, has resulted in correlates of that element that clarify, though they do not shed all the light on we would wish, the contribution of peer interactions to the dynamics of science.

We used a chain-letter technique similar to that of Kadushin (1974) for sampling the sociometric relations among an intellectual elite. Differential geometry is an illustrative specialty. We wrote to the editors of key journals in that specialty, asking them to name ten experts in that field from whom they would like to receive manuscripts or whom they would like to have as referees for manuscripts they rcceivc. We askcd the cxpcrts thus namcd to name cxpcrts whose papers they would like to read or whose judgments about their own manuscripts they would value.

This method is subject to at least one sampling bias. The data collection instrument used the mail (electronic or conventional) and not all of the experts who received a questionnaire replied. While 1460 experts were nominated, we reccived rcsponses from only 300 of them, or 20 per cent, by the end of Round 3. (The actual response rate is higher than 20 per cent. We were unable to locate some experts to send them their questionnaires. In addition, almost 500 experts were first named in the third round and we have not yet completed our analysis of the database comprised of the responses of those in the group who did reply.) If the experts who did not respond differ from those who did respond, then our sample is biased. This could result in inferences that distort reality. 
We examined the values of variables characterizing each expert and each respondent to see if we could compare the respondents and non-respondents with regard to some of these variables. Information about each nominee's employer was available, as was specification of the country where each person works. We decided to use this information to compare the respondents with those non-respondents experts who did receive a questionnaire.

\section{COUNTRY OF RESPONDENTS VS. NON-RESPONDENTS}

The respondents to our questionnaire come from a total of 19 countries. The non-respondents are even more diversely spread over 29 countries. To perform any analysis on the data required that the country of each expert be mapped into a smaller number of categories. Accordingly, we decided on seven regions of the world and assigned each expert to the appropriate region. The results for respondents and non-respondents are shown below in Table 1.

TABLE 1. Actual response for different regions of the world

\begin{tabular}{lccccccccc}
\hline & & \multicolumn{2}{c}{$\begin{array}{c}\text { North } \\
\text { America Kingdom }\end{array}$} & $\begin{array}{c}\text { United } \\
\text { Javan }\end{array}$ & $\begin{array}{c}\text { Scandin- } \\
\text { avia }\end{array}$ & $\begin{array}{c}\text { West } \\
\text { Europe }\end{array}$ & $\begin{array}{c}\text { East } \\
\text { Europe }\end{array}$ & Other & Total \\
\hline $\begin{array}{l}\text { Non-respondents } \\
\text { Respondents }\end{array}$ & 14 & 436 & 51 & 13 & 79 & 6 & 8 & 607 \\
\hline Total & 12 & 213 & 29 & 12 & 32 & 2 & 1 & 301 \\
\hline
\end{tabular}

If the experts who chose to respond were equally likely to live in any country, we could predict the number of respondents and non-respondents for each region from the totals for regions and for response. The expected values differed little from those actually recorded (Table 2).

TABLE 2. Expected responses for different regions of the world

\begin{tabular}{lrrrrrrr}
\hline & Japan & $\begin{array}{c}\text { North } \\
\text { America }\end{array}$ & $\begin{array}{c}\text { United } \\
\text { Kindom }\end{array}$ & $\begin{array}{c}\text { Scandin- } \\
\text { avia }\end{array}$ & $\begin{array}{c}\text { West } \\
\text { Europe }\end{array}$ & $\begin{array}{c}\text { East } \\
\text { Europe }\end{array}$ & Other \\
\hline Non-respondents & 17.38 & 433.86 & 53.48 & 16.71 & 74.20 & 5.35 & 6.02 \\
Respondents & 8.62 & 215.14 & 26.52 & 8.29 & 36.80 & 2.65 & 2.98 \\
\hline
\end{tabular}

The calculated value of chi-square was 6.97 , well below the value of 10.65 , for which the probability that a random sample gives a better fit is 0.1 , with the corresponding probability of 0.3 for 6 degrees of freedom. Therefore, we have reason to believe that the country where an expert works had no impact on whether the person chose to respond to the questionnaire or not.

\section{PRESTIGE OF EMPLOYER OF RESPONDENTS VS. NON-RESPONDENTS}

Employment varied even more than country and required a more complex mapping. The employing institutions were ranked, using a four-point scale. A 
rank of 1 meant a very prestigious institution and a rank of 4 meant an ordinary institution. The ranking scale was somewhat arbitrary, based as it was on our evaluation of where institutions would fall. A rank of 1 was the least subjective since it was assigned to institutions in the USA-approximately ten in number-abnut whom various established rankings agree are the premiere schools. In some cases where we did not feel comfortable in assigning a rank we let that employer fall in the 'not applicable' category. For those who might argue about the appropriateness of how employers were ranked in categories 2 , 3 and 4, we reply that we were using these ranks only as a consistent tool for comparing the pools of respondents and non-respondents, not as a means of finalizing judgment concerning employer eminence. We were assessing the reliability of our effort to chart the network of peers as it is. We were not trying to correlate 'visibility' with 'eminence of employer'. The number of respondents and the number of non-respondents from each ranked institution was tabulated. Not surprisingly, since all the people named in these chain letters are considered by their nominators to be experts, more of them (both respondents and non-respondents) work at prestigious institutions than otherwise. We checked for the possibility that more of those who responded were at prestigious (or ordinary) institutions than those who failed to respond. The distribution of respondents and non-respondents at the levels of institutions which we were able to rank is shown in Table 3.

TABLE 3. Actual response according to institutional eminence

\begin{tabular}{lrrrrrr}
\hline $\begin{array}{l}\text { Rank category } \\
\text { of institution }\end{array}$ & 1 & 2 & 3 & 4 & $\begin{array}{c}\text { Not } \\
\text { applicable }\end{array}$ & Total \\
\hline $\begin{array}{l}\text { Non-respondents } \\
\text { Respondents }\end{array}$ & 149 & 126 & 75 & 45 & 22 & 417 \\
\hline Total & 70 & 65 & 52 & 23 & 11 & 221 \\
\hline
\end{tabular}

Using the total values, again, to calculate the expected values for respondents and non-respondents from each level of institutional eminence, we get, again values differing little from those observed (Table 4).

TABLE 4. Expected response according to institutional eminence

\begin{tabular}{lrrrrr}
\hline $\begin{array}{l}\text { Rank category } \\
\text { of institution }\end{array}$ & 1 & 2 & 3 & 4 & $\begin{array}{c}\text { Not } \\
\text { applicable }\end{array}$ \\
\hline $\begin{array}{l}\text { Non-respondents } \\
\text { Respondents }\end{array}$ & 143.14 & 124.84 & 83.01 & 44.45 & 11.43 \\
\hline
\end{tabular}

The chi-square calculated value was 3.00 , well below the 0.1 value of 7.79 , even below the 0.5 value of 3.36 . Hence we can assert with considerable confidence that the level of eminence of the experts' employers did not account 
for their willingness to respond to the questionnaire. Those at very prestigious institutions answered as readily as those at ordinary ones.

We conclude from the analysis of the two characteristics available for all nominated experts that there is no difference between the people who answered the questionnaire and those who did not, at least on the two dimensions checked. We see no reason to expect that non-respondents differ from respondents in other ways, though our check on degree of bias does not statistically explore other possibilities. If there is an explanation for nonresponse that would have an impact on the survey results, we have not identified it. Therefore, we feel reasonably confident that the findings presented can be generalized to the entire population we studied and that they are free of distortion.

\section{APPENDIX: COMMENTS FROM NON-RESPONDENTS}

'I assume you obtained my name by error. Your study appears to be aimed at research scientists... my major concerns centre on the management and administration of a research library'.

'I am involved in so many fields that it would take much time and space to name all the people I might suggest as referees, depending on the specifics. I would be most reluctant to name just a few 'big names' in each area, since there is very little correlation in general between the visibility of a name and the degree of my respect for that individual'.

'As an author of a notorious book, I get listed as a practitioner (apparently, even as an expert) in fields I barely know by name. That has apparently happened on this occasion for by no stretch of the imagination do I belong in any of the fields you list. Probably I do belong in two other fields, but I am pretty much a loner in both, and I tend to pick up advice from whoever is near at hand'.

'My difficulty is that I really do not know what my field is ... the nature of (my) discipline, as I interpret it, is such that I feel free to roam many different fields. When in graduate school, I was asked what I specialized in, and I replied that I specialized in generalizations. So I find it difficult both to be named as within a network, or even to name those 1 would regard as individuals to whom I could be linked. If you want to establish a new field called 'mavericks', I would try to establish other members of the genus. But since mavericks, by definition, run away from each other, this too might be difficult'.

\section{ACKNOWLEDGEMENTS}

The authors would like to express their appreciation for the assistance of Alex Blaivas and Peter Lenk. This research was supported by a National Science Foundation grant, 1ST-8007433, 'Dynamics in the Organization of Scientific Specialties'.

\section{REFERENCES}

BLAIVAS, A., KOCHEN, M. and CRICKMAN, R. (1981). Geographic patterns of choice among peers. Social Science Information Studies, 1, 283-295.

GOODFIELD, J. (1981). An imagined world. New York: Harper \& Row.

Judson, H. (1979). The eighth day of creation. Austin: S \& S Press.

KADUSHIN, C. (1974). The American intellectual elite. Boston: Little and Brown. 